\title{
Sodium requirement for capacitation and membrane fusion during the guinea-pig sperm acrosome reaction
}

\author{
R. V. Hyne, Ruth E. Higginson, Debbie Kohlman and A. Lopata \\ Reproductive Biology Unit and Department of Obstetrics and Gynaecology, Royal Women's Hospital \\ University of Melbourne, Parkville, Victoria 3052, Australia
}

\begin{abstract}
Summary. Guinea-pig spermatozoa, incubated in a minimal culture medium (MCM$\mathrm{PL}$ ) containing $150 \mathrm{mM}-\mathrm{Na}^{+}$and no added $\mathrm{K}^{+}$, capacitate within $2 \mathrm{~h}$ and respond to added $\mathrm{Ca}^{2+}$ with maximal percentage of acrosome reactions. When spermatozoa, initially capacitated in Medium MCM-PL, were washed and resuspended in salinebased media, the motile spermatozoa showed acrosome reactions only in response to added $\mathrm{Ca}^{2+}$ at an extracellular $\mathrm{pH}>7.4$. In contrast, resuspension of capacitated spermatozoa into isotonic sucrose or choline-based media containing no added $\mathrm{Na}^{+}$ and $\mathrm{K}^{+}(\mathrm{pH} 7.8)$ did not support acrosome reactions in response to the addition of $\mathrm{Ca}^{2+}$. Examination under the electron microscope showed that these spermatozoa responded to added $\mathrm{Ca}^{2+}$ with swelling or cavitation of the acrosomal matrix but fusion of the plasma membrane and acrosomal membrane did not occur. Treatment of spermatozoa with monensin, a monovalent cationic ionophore, induced rapid acrosome reactions in the presence of extracellular $\mathrm{Ca}^{2+}$ and $\mathrm{Na}^{+}$. In contrast, spermatozoa incubated for $3 \mathrm{~h}$ in a sucrose-based $\mathrm{Na}^{+}$-deficient medium or Medium MCM-PL containing $10 \mathrm{mM}-\mathrm{KCl}$ failed to give a significant percentage of acrosome reactions in response to the addition of $\mathrm{Ca}^{2+}$, but the addition of ouabain $(0.1 \mathrm{mM})$ prevented the $\mathrm{K}^{+}$inhibition. Amiloride, a sodium channel blocker in various other tissues, retarded the development of acrosome reactions of spermatozoa incubated in Medium MCM-PL. Based on these data, it appears that an increase in intracellular $\mathrm{Na}^{+}$has a functional role in acquisition of guinea-pig sperm fertilizing ability.
\end{abstract}

\section{Introduction}

To acquire fertilizing capacity, spermatozoa must undergo the 'acrosome reaction', a fusion and vesiculation of the outer acrosomal membrane and overlying plasma membrane (Barros, Bedford, Franklin \& Austin, 1967). The involvement of a regulatory mechanism consisting of, in part, changes in the movement of ions across the sperm membranes has been suggested (Schackmann \& Shapiro, 1981). Like other membrane fusion events (Poste \& Allison, 1973), the acrosome reaction of mammalian (Yanagimachi \& Usui, 1974; Miyamoto \& Ishibashi, 1975) and invertebrate (Dan, $1954,1967)$ spermatozoa is completely dependent on the presence of extracellular $\mathrm{Ca}^{2+}$. Altered $\mathrm{Ca}^{2+}$ permeability appears to represent one of the primary signals for the induction of the sperm acrosome reaction (Yanagimachi, 1975; Singh, Babcock \& Lardy, 1978), although the mechanism for the change in $\mathrm{Ca}^{2+}$ transport is unknown. Biochemically and ultrastructurally the acrosome reaction has many similarities to the release of secretory products from intracellular granules by exocytosis (Poste \& Allison, 1973). The requirement for $\mathrm{Ca}^{2+}$ in the stimulus-secretion of zymogen 
granules is well established. Recent studies indicate that a rise in the cytoplasmic $\mathrm{Na}^{+}$concentration also stimulates the secretory activity of cells (Suchard, Lattanzio, Rubin \& Pressman, 1982).

The acrosome reaction of sea-urchin spermatozoa requires extracellular $\mathrm{Na}^{+}$(Schackmann, Eddy \& Shapiro, 1978). It is inhibited by an increase in extracellular $\mathrm{K}^{+}$(Schackmann et al., 1978), is pH dependent (Collins \& Epel, 1977; Hyne \& Garbers, 1982) and is also accompanied by uptake of ${ }^{45} \mathrm{Ca}^{2+}$ and ${ }^{22} \mathrm{Na}^{+}$, as well as release of $\mathrm{K}^{+}$and $\mathrm{H}^{+}$(Schackmann \& Shapiro, 1981). Induction of the sea-urchin sperm acrosome reaction leads to depolarization of the membrane potential (Schackmann, Christen \& Shapiro, 1981).

The acrosome reaction in mammals occurs only after the spermatozoa have undergone a series of currently undefined biochemical changes described as 'capacitation'. An increase in the ratio of $\mathrm{K}^{+}$to $\mathrm{Na}^{+}$in the incubation medium has been shown to stimulate fertilization of rat oocytes in vitro (Toyoda \& Chang, 1974) and a $\mathrm{K}^{+}$influx appears to accompany the hamster sperm acrosome reaction (Mrsny \& Meizel, 1981), but whether these effects were on sperm capacitation and/or the acrosome reaction is not clear. In contrast, capacitation of guinea-pig spermatozoa is inhibited by extracellular $\mathrm{K}^{+}$(Rogers, Ueno \& Yanagimachi, 1981). Other studies also suggest that inorganic ions have a role in the initiation and maintenance of sperm motility. The requirement of $\mathrm{Na}^{+}$for the maintenance of the motility of rat spermatozoa, after removal from the epididymis, has been attributed to an increase in the intracellular $\mathrm{pH}$ via a $\mathrm{Na}^{+} / \mathrm{H}^{+}$exchange (Wong, Lee \& Tsang, 1981).

Synchronous acrosome reactions in a large number of motile guinea-pig spermatozoa can be obtained by preincubation of spermatozoa to capacitate them in $\mathrm{Ca}^{2+}$-free medium and then stimulation of the acrosome reaction by the addition of $\mathrm{Ca}^{2+}$ as described by Yanagimachi \& Usui (1974). In the present study, experiments were undertaken to establish the minimal ionic requirements that would support the occurrence of acrosome reactions of spermatozoa that had previously been capacitated and to gain information on how $\mathrm{Ca}^{2+}$ transport is controlled and altered during the capacitating procedure.

\section{Materials and Methods}

Media. The basic sperm capacitating medium (MCM-PL) was a modified $\mathrm{Ca}^{2+}$-free minimal culture medium of Barros (1974) containing $106 \mathrm{~mm}-\mathrm{NaCl}, 1.0 \mathrm{~mm}-\mathrm{MgCl}_{2}, 25 \cdot 1 \mathrm{~mm}-\mathrm{NaHCO}_{3}$, $0.25 \mathrm{~mm}$-sodium pyruvate, $20 \mathrm{~mm}$-sodium lactate, penicillin (100 units $/ \mathrm{ml})$ and streptomycin sulphate $(50 \mu \mathrm{g} / \mathrm{ml})$. It was essential to include $1 \mathrm{mM}^{-\mathrm{Mg}^{2}}$ in all $\mathrm{Ca}^{2+}$-free media to maintain sperm motility. In some experiments attempts were made to capacitate the spermatozoa by incubating the cells in a $\mathrm{Na}^{+}$-deficient medium $\left(\sim 45 \mathrm{mM}-\mathrm{Na}^{+}\right)$containing $212 \mathrm{mM}$-sucrose, $1.0 \mathrm{~mm}-\mathrm{MgCl}_{2}, 25.1 \mathrm{mM}-\mathrm{NaHCO}_{3}, 0.25 \mathrm{~mm}$-sodium pyruvate, $20 \mathrm{~mm}$-sodium lactate, penicillin $(100$ units $/ \mathrm{ml})$ and streptomycin sulphate $(50 \mu \mathrm{g} / \mathrm{ml})$ or a modified MCM-PL medium containing $10 \mathrm{~mm}-\mathrm{KCl}$.

In some experiments, after the initial preincubation in Medium MCM-PL, the spermatozoa were centrifuged twice and resuspended in medium containing $145 \mathrm{mM}-\mathrm{NaCl}, 1 \mathrm{mM}-\mathrm{MgCl}_{2}$ and $10 \mathrm{mM}$-Tris buffered between $6.6(301 \mathrm{mosmol} / \mathrm{kg})$ and $8.2(312 \mathrm{mosmol} / \mathrm{kg})$ with $1 \mathrm{M}-\mathrm{HCl}$ at $24^{\circ} \mathrm{C}$. In the experiments using $\mathrm{Na}^{+}$-deficient media, the medium had a similar composition except that various concentrations of choline chloride were substituted for $\mathrm{NaCl}$ and the $\mathrm{pH}$ adjusted to 7.8. The $\mathrm{Na}^{+}$- and $\mathrm{K}^{+}$-free media contained $178 \mathrm{mM}$-choline chloride or $300 \mathrm{mM}$-sucrose together with $1 \mathrm{mM}-\mathrm{MgCl}_{2}$ and $10 \mathrm{mM}-$ Tris buffered at $\mathrm{pH} 7.8$ and no added $\mathrm{Na}^{+}$or $\mathrm{K}^{+}$. The osmolarity of all media varied between 300 and $315 \mathrm{mosmol} / \mathrm{kg}$.

Sperm preparation and incubation procedure. Adult male guinea-pigs (Dunkin-Hartley or Monash University outbred strain) of $>700 \mathrm{~g}$ weight were anaesthetized with ether and killed by cervical dislocation. A testis was removed, the distal portion of one cauda epididymidis attached to 
the vas deferens was obtained and the spermatozoa were isolated by flushing the lumen with $0.9 \%$ $(\mathrm{w} / \mathrm{v}) \mathrm{NaCl}$ as described previously (Hyne \& Garbers, 1979, 1981). The spermatozoa were washed once by centrifugation $\left(400 \mathrm{~g}, 10 \mathrm{~min}\right.$ ) and resuspended in $0.9 \% \mathrm{NaCl}$. When $\mathrm{Na}^{+}$-free experiments were undertaken, the cells were collected and washed in an isotonic sucrose-based medium

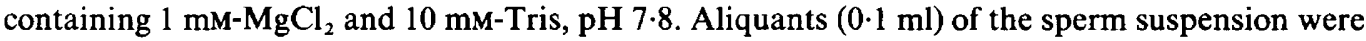
added to $0.9 \mathrm{ml}$ of the capacitating medium in sterile polystyrene tubes with caps (Falcon Plastics, No. 2003, Oxnard, California). All incubations were initiated by the addition of spermatozoa $(0 \cdot 5$ $\times 10^{7}$ spermatozoa/ml) to the assay mixtures. The tubes were placed horizontally on a shaker (Yankee, Clay Adams, Parsippany, New Jersey), rotating at 60 strokes per min in an incubator at $37^{\circ} \mathrm{C}$ with air as the atmosphere.

In some experiments, after an initial preincubation in Medium MCM-PL for $135 \mathrm{~min}$ (unless otherwise stated), the spermatozoa were washed twice by centrifugation $(700 \mathrm{~g}, 10 \mathrm{~min})$ and resuspended in a different medium. Then $\mathrm{Ca}^{2+}(5 \mathrm{~mm}$, final concentration) was added and after a 10-min incubation the percentages of motile spermatozoa and of acrosome reactions were assessed.

Determination of sperm motility, capacitation and acrosome reactions. At various times during an incubation after the addition of $\mathrm{Ca}^{2+}$, small aliquants of the sperm suspension were transferred to a ceramic ring slide (Clay Adams) and mounted under a coverslip. At least 100 spermatozoa were examined to estimate the percentage of motile cells within the entire population of spermatozoa and the percentage of cells without a visible acrosomal cap within the motile sperm population by phase-contrast microscopy at $\times 320$. The time required for capacitation is defined here as the incubation time required before the acrosome reaction can be observed in response to the acute addition of $\mathrm{Ca}^{2+}$.

Addition of ionophores, ouabain and amiloride. Ionophores were dissolved in ethanol in stock solutions of $2-20 \mathrm{mM}$. The ionophores or ethanol $(5 \mu \mathrm{l})$ were added to culture tubes containing $900 \mu \mathrm{l}$ Medium MCM-PL or a medium consisting of $300 \mathrm{~mm}$-sucrose, $1 \mathrm{mM}-\mathrm{MgCl}_{2}$ and $10 \mathrm{~mm}$-Tris (pH 7.8). In some cases, $5 \mathrm{~mm}-\mathrm{CaCl}_{2}$ (final concentration) were also included in the treatments. Incubations were initiated by the addition of $100 \mu \mathrm{l}$ of the stock sperm suspension to the culture tubes.

Amiloride $(0.5 \mathrm{~mm}$, final concentration) was added to $1.0 \mathrm{ml}$ of a sperm suspension preincubated for 135-195 min in Medium MCM-PL and the mixture was incubated for an additional $30 \mathrm{~min}$. In other experiments, amiloride was added to the medium before the addition of the spermatozoa, and the final mixture was incubated for $3 \mathrm{~h} . \mathrm{Ca}^{2+}(5 \mathrm{mM}$, final concentration) was then added to the sperm suspension and after $10 \mathrm{~min}$ the sperm motility and the sperm acrosome reaction rate were assessed.

Ouabain ( $0 \cdot 1 \mathrm{mM}$, final concentration) and/or $\mathrm{KCl}(10 \mathrm{mM}$, final concentration) was added to culture tubes containing $900 \mu \mathrm{l}$ Medium MCM-PL and incubations were initiated by the addition of $100 \mu \mathrm{l}$ of the stock sperm suspension to the culture tubes.

Acid efflux measurements during sperm acrosome reactions. Sperm suspensions $(1.5 \mathrm{ml})$, initially preincubated in Medium MCM-PL for $140 \mathrm{~min}$, were washed twice by centrifugation $(700 \mathrm{~g}$, $10 \mathrm{~min}$ ) and resuspended in medium containing $150 \mathrm{mM}-\mathrm{NaCl}$ or $178 \mathrm{~mm}$-choline chloride with $1 \mathrm{mM}-\mathrm{MgCl}_{2}$ and $1 \mathrm{mM}-\mathrm{NaHCO}_{3}$ as a weak buffer and then transferred to a $2 \cdot 0-\mathrm{ml}$ capacity temperature-control chamber fitted with a semi-micro-combination $\mathrm{pH}$ electrode $(\mathrm{N}$. J. Jones Scientific Instruments, Melbourne, Australia). The sperm concentration was $0.5 \times 10^{7} \mathrm{ml}$ and the suspension was gently stirred with a magnetic stirrer. Changes in $\mathrm{pH}$ in response to the addition of $\mathrm{Ca}^{2+}$ (5 mM, final concentration) was measured with a $\mathrm{pH}$ meter (N. J. Jones Scientific Instruments).

Chemicals. Ouabain octahydrate, and gramicidin S were purchased from Sigma. Amiloride hydrochloride was a gift from Merck, Sharp \& Dohme (Australia) Pty Ltd and monensin (sodium salt) was a gift from Eli Lilly (Australia) \& Co. Choline chloride was obtained from Hopkin and Williams (Chadwell Heath, Essex, U.K.). All common chemicals were purchased from Ajax (Melbourne, Australia) or Sigma (St Louis, Missouri, U.S.A.). 
Sperm preparation for electron microscopy. Spermatozoa were fixed in $3 \cdot 5 \%$ glutaraldehyde in $0 \cdot 1$ M-cacodylate buffer, $1.5 \mathrm{mM}-\mathrm{CaCl}_{2}(\mathrm{pH} \mathrm{7.3)}$ ) for $30 \mathrm{~min}$ at room temperature. Fixed spermatozoa were centrifuged $(1000 \mathrm{~g}, 10 \mathrm{~min})$, resuspended in $0.1 \mathrm{M}$-cacodylate $(0.5 \mathrm{ml})$, transferred to a glass test-tube $(18 \times 5 \mathrm{~mm})$ and stored at $4^{\circ} \mathrm{C}$ until embedded. The spermatozoa were centrifuged and the pellet post-fixed with $1 \%$ osmium tetroxide in $0 \cdot 1 \mathrm{M}$-cacodylate buffer for $1 \mathrm{~h}$. After a brief buffer wash, the pellets were dehydrated through a series of graded ethanol to absolute ethanol, followed by absolute acetone, infiltrated with Spurr resin and embedded in Beem capsules.

For light microscopy, survey sections of $0.5 \mu \mathrm{m}$ were cut (Reichert OMU4 Ultracut) and stained with toluidine blue and viewed under a Leitz Dialux microscope under oil $(\times 1250)$.

For electron microscopy, gold-coloured sections were stained with uranyl acetate, followed by lead citrate and examined with a Philips 401 transmission electron microscope.

\section{Results}

\section{Effect of $\mathrm{pH}$ on the response of capacitated spermatozoa to $\mathrm{Ca}^{2+}$}

The occurrence of acrosome reactions within $10 \mathrm{~min}$ of the addition of $\mathrm{Ca}^{2+}$ was the standard indicator of prior capacitation (Hyne \& Garbers, 1979, 1981). After a preincubation period of $0.5 \mathrm{~h}$ in Medium MCM-PL motile spermatozoa showed acrosome reactions within 10 min of the addition of $\mathrm{Ca}^{2+}$, indicating that capacitation had occurred in the absence of added $\mathrm{Ca}^{2+}$. The acrosome reaction was maximal after a $2 \mathrm{~h}$ preincubation, when $60-80 \%$ of the motile spermatozoa responded.

Experiments were undertaken to establish the minimal ionic requirements of culture media that could not inhibit acrosome reactions of spermatozoa that had previously been capacitated by incubation in Medium MCM-PL. After incubation in Medium MCM-PL for $135 \mathrm{~min}$ the spermatozoa were centrifuged twice and resuspended in a saline-based medium containing $1 \mathrm{~mm}-$ $\mathrm{MgCl}_{2}$ and $10 \mathrm{mM}$-Tris buffered at various $\mathrm{pH}$ values between $\mathrm{pH} 6.6$ and $8 \cdot 2$. When $\mathrm{Ca}^{2+}$ was added, the motile spermatozoa showed acrosome reactions within $10 \mathrm{~min}$ only with a $\mathrm{pH}>7 \cdot 4$, with a maximal response at $\mathrm{pH}>7 \cdot 8$ (Text-fig. 1a). If the capacitated spermatozoa were incubated longer in medium buffered to a $\mathrm{pH}$ of 7.0 or less, no acrosome reactions occurred even after $1 \mathrm{~h}$.
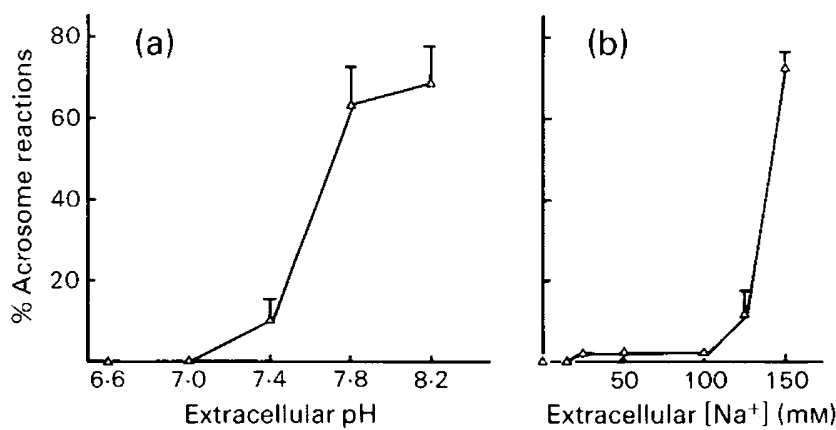

Text-fig. 1. The response of capacitated guinea-pig spermatozoa to $\mathrm{Ca}^{2+}$ at various extracellular $\mathrm{pH}$ values or $\mathrm{Na}^{+}$concentrations. Spermatozoa were capacitated by incubation in Medium MCM-PL for $135 \mathrm{~min}$ before being washed twice and re-suspended in (a) an isotonic saline-based medium containing $1 \mathrm{mM}-\mathrm{MgCl}_{2}$ and $10 \mathrm{mM}$-Tris buffered at the various $\mathrm{pH}$ values indicated or (b) isotonic choline-based media containing various concentrations of $\mathrm{Na}^{+}$ as indicated. $\mathrm{Ca}^{2+}(5 \mathrm{mM})$ was then added and the percentage of motile spermatozoa without acrosomal caps was assessed after $10 \mathrm{~min}$. The percentage of motile spermatozoa was not different for any of the treatments and varied between 50 and $65 \%$. Values shown are the mean \pm s.e.m. of (a) 3 animals or (b) 4 animals. 
Therefore, all further experiments with capacitated spermatozoa were conducted with media buffered at a pH of 7.8. It was essential to include $1 \mathrm{~mm}-\mathrm{Mg}^{2+}$ in all media to maintain sperm motility in $\mathrm{Ca}^{2+}$-free media. The capacitated spermatozoa maintained good motility in media containing no exogenous substrates for up to $2 \mathrm{~h}$.

\section{$\mathrm{Na}^{+}$requirement for the acrosome reaction}

Spermatozoa initially capacitated by preincubation for $135 \mathrm{~min}$ in Medium MCM-PL were washed twice by centrifugation and resuspended in isotonic $\mathrm{Na}^{+}$and $\mathrm{K}^{+}$-free choline- or sucrosebased media (containing no added $\mathrm{Na}^{+}$and $\mathrm{K}^{+}$) buffered at $\mathrm{pH} 7 \cdot 8$. After the addition of $\mathrm{Ca}^{2+}(5$ $\mathrm{mM}$ ), no acrosome reactions were observed after incubation for $10 \mathrm{~min}$ (Table 1). Resuspending the capacitated spermatozoa in an isotonic $\mathrm{K}^{+}$-containing medium with $\mathrm{Ca}^{2+}$ but no added $\mathrm{Na}^{+}$gave acrosome reactions, although the percentage was considerably more variable (Table 1). If capacitated spermatozoa were resuspended in choline-based media containing various concentrations of $\mathrm{Na}^{+}$and no added $\mathrm{K}^{+}$buffered at $\mathrm{pH} \mathrm{7.8,} \mathrm{the} \mathrm{spermatozoa} \mathrm{gave} \mathrm{acrosome} \mathrm{reactions} \mathrm{in}$ response to the addition of $\mathrm{Ca}^{2+}$ only when the $\mathrm{Na}^{+}$concentration was $>125 \mathrm{mM}$ (Text-fig. 1b). If the incubation was continued for up to $1 \mathrm{~h}$ after the addition of $\mathrm{Ca}^{2+}$ in the low $\mathrm{Na}^{+}$media, no increase in the percentage of acrosome reaction was observed in any of the treatments.

Table 1. The response of capacitated spermatozoa to $\mathrm{Ca}^{2+}$ when suspended in various isotonic media buffered at $\mathrm{pH} 7 \cdot 8$

\begin{tabular}{lc}
\hline \multicolumn{1}{c}{ Resuspension medium } & $\%$ Acrosome reactions \\
\hline $150 \mathrm{mM}-\mathrm{NaCl}$ & $62 \cdot 3 \pm 4.9$ \\
$150 \mathrm{mM}-\mathrm{KCl}$ & $43 \cdot 5 \pm 17 \cdot 6$ \\
$178 \mathrm{mM}-\mathrm{Choline}$ chloride & $<1$ \\
$300 \mathrm{mM}-$ Sucrose & $<1$ \\
\hline
\end{tabular}

Spermatozoa were capacitated by incubation in Medium MCM-PL for 135 min before being washed twice by centrifugation and resuspended in the saline-based or $\mathrm{Na}^{+}$-free media indicated. The media contained in addition $1 \mathrm{~mm}$ $\mathrm{MgCl}_{2}$ and $10 \mathrm{~mm}$-Tris buffered to $\mathrm{pH} 7 \cdot 8 . \mathrm{Ca}^{2+}(5 \mathrm{mM})$ was then added and the percentage of motile spermatozoa without acrosomal caps was assessed after $10 \mathrm{~min}$. The percentage of motile spermatozoa was not different for any of the treatments and varied between 50 and $60 \%$. Values shown are the mean \pm s.e.m. for 4 animals.

The dependence of the guinea-pig sperm acrosome reaction on extracellular $\mathrm{Na}^{+}$suggested that $\mathrm{Na}^{+}$transport could be involved in the activation process. To determine whether the membrane fusion was associated with a $\mathrm{Na}^{+} / \mathrm{H}^{+}$exchange, capacitated spermatozoa, suspended in an isotonic medium containing no added $\mathrm{Na}^{+}$and $\mathrm{K}^{+}$, were incubated with $25 \mathrm{mM}-\mathrm{NH}_{4} \mathrm{Cl}$ and $5 \mathrm{mM}-$ $\mathrm{Ca}^{2+}$. Ammonium is known to cause an increase in intracellular $\mathrm{pH}$ and can activate cells even in $\mathrm{Na}^{+}$-free media (Johnson, Epel \& Paul, 1976; Winkler \& Grainger, 1978). However, this treatment did not overcome the block to the induction of the acrosome reaction. Direct measurement of acid efflux from capacitated spermatozoa suspended in saline-based medium or medium containing no added $\mathrm{Na}^{+}$showed that the addition of $\mathrm{Ca}^{2+}$ caused slight acidification $(\Delta \mathrm{pH}=0 \cdot 1)$ of the extracellular medium in both treatments.

Treatment of capacitated spermatozoa suspended in Medium MCM-PL with 0.5 mMamiloride, a sodium channel blocker in various other tissues (Salako \& Smith, 1970; Smith, Macara, Levenson, Housman \& Cantley, 1982), for $30 \mathrm{~min}$ before the addition of $\mathrm{Ca}^{2+}$ retarded 
induction of the acrosome reactions compared with untreated spermatozoa (Text-fig. 2a). Higher concentrations of amiloride inhibited the sperm motility. If amiloride was added at the start of the incubation, the sperm acrosome reaction was reduced in a dose-dependent manner, with $0.5 \mathrm{mM}$ amiloride reducing the percentage of acrosome reactions by approximately $65 \%$ after $3 \mathrm{~h}$ (Textfig. 2b).
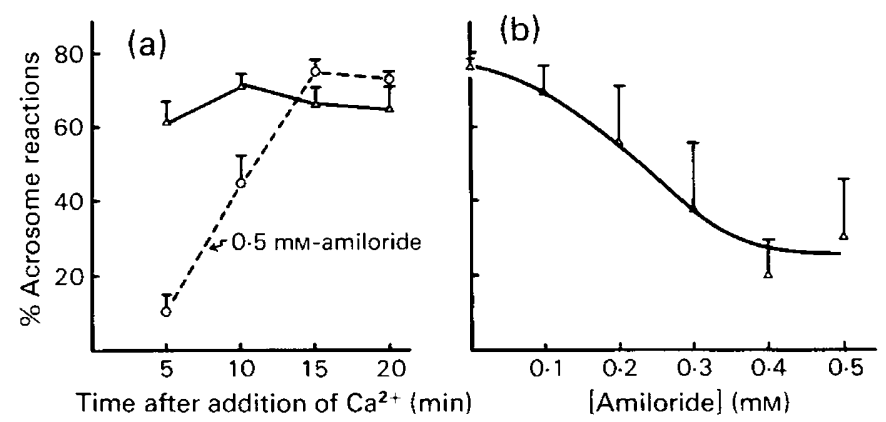

Text-fig. 2. Effect of amiloride, a sodium channel blocker, on the guinea-pig sperm acrosome reaction. (a) Spermatozoa were capacitated by incubation in Medium MCM-PL for 135-195 min before the addition of $0.5 \mathrm{~mm}$-amiloride $\left(\mathrm{O}_{--} \mathrm{O}\right)$ and the incubation was then continued for an additional $30 \mathrm{~min}$. Control treatment $(\triangle-\triangle)$ consisted of spermatozoa incubated in Medium MCM-PL with no other addition for the same time periods. $\mathrm{Ca}^{2+}(5 \mathrm{mM}$, final conc.) was then added and the percentage of motile spermatozoa without acrosomal caps was assessed at the times indicated. (b) Spermatozoa were incubated for $3 \mathrm{~h}$ in Medium MCM-PL in the presence of the various concentrations of amiloride indicated. $\mathrm{Ca}^{2+}(5 \mathrm{mM}$, final conc.) was added for the last $10 \mathrm{~min}$ of the incubation and the percentage of acrosome reactions $(\Delta-\Delta)$ was then assessed. The percentage of motile spermatozoa was not different for any of the treatments and varied between 50 and $60 \%$. Values are mean \pm s.e.m. for 4 (a) and 3 (b) animals.

These results indicate that the sperm capacitation process may involve an increase in $\mathrm{Na}^{+}$ influx. Cells suspended in an isotonic medium containing no extracellular $\mathrm{Na}^{+}$and $\mathrm{K}^{+}$may lose intracellular $\mathrm{Na}^{+}$due to an uncoupled efflux of $\mathrm{Na}^{+}$through $\left(\mathrm{Na}^{+}, \mathrm{K}^{+}\right)$-ATPase (Robinson \& Flashner, 1979). Whether this effect contributes to the inhibition of the sperm acrosome reaction was examined by treating capacitated spermatozoa suspended in a $\mathrm{Na}^{+}$- and $\mathrm{K}^{+}$-free medium (containing no added $\mathrm{Na}^{+}$and $\mathrm{K}^{+}$) with $1 \mathrm{mM}$-ouabain, a specific inhibitor of $\left(\mathrm{Na}^{+}, \mathrm{K}^{+}\right)$-ATPase (Robinson \& Flashner, 1979). However, neither this treatment nor the addition of $5 \mathrm{mM}-\mathrm{K}^{+}$to the $\mathrm{Na}^{+}$-free medium removed the inhibition of the acrosome reaction.

\section{Effect of ionophores and ouabain on sperm capacitation}

Guinea-pig spermatozoa incubated in Medium MCM-PL underwent rapid acrosome reactions when incubated with $\mathrm{Ca}^{2+}$ and monensin $(30-50 \mu \mathrm{M})$, a monovalent cationic ionophore which catalyses $\mathrm{Na}^{+} / \mathrm{H}^{+}$exchange across cell membranes. The acrosome reactions induced by treatment with monesin were completely dependent upon the presence of both extracellular $\mathrm{Ca}^{2+}$ and $\mathrm{Na}^{+}$ and occurred within $10 \mathrm{~min}$ after addition of the ionophore (Text-fig. 3). The spermatozoa with acrosome reactions induced by treatment with monensin initially showed good motility, but after 20-45 min the spermatozoa were immotile. If the spermatozoa were treated with monensin in the absence of extracellular $\mathrm{Ca}^{+}$, the motile spermatozoa did not undergo rapid acrosome reactions, but maintained good motility after $45 \mathrm{~min}$. 


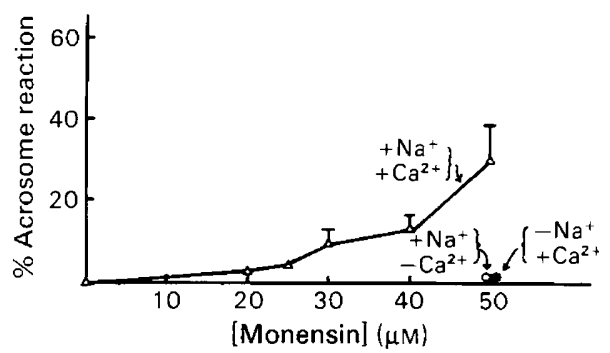

Text-fig. 3. Induction of guinea-pig sperm acrosome reactions by various concentrations of monensin. Freshly collected spermatozoa were incubated in Medium MCM-PL $\left(+\mathrm{Na}^{+}\right)$or an isotonic sucrose-based medium containing no added $\mathrm{Na}^{+}$and $\mathrm{K}^{+}\left(-\mathrm{Na}^{+}\right)$. All treatments had in addition $5 \mathrm{mM}-\mathrm{Ca}^{2+}$ (unless otherwise indicated) and monensin at the final concentrations indicated. As a control, absolute ethanol $(0.5 \%)$ was added to the treatment containing no ionophore. The percentage of motile spermatozoa without acrosomal caps in each treatment was assessed after incubation for $10 \mathrm{~min}$. The percentage of motile spermatozoa was not different for any of the treatments and varied between 60 and $70 \%$. Values shown are the mean \pm s.e.m. of 5 animals.

Gramicidin $\mathrm{S}(10 \mu \mathrm{M})$, a monovalent cationic ionophore which shows little selectivity between $\mathrm{Na}^{+}$and $\mathrm{K}^{+}$(Goodall, 1970), also induced rapid acrosome reactions in $\mathrm{C} \mathrm{Ca}^{2+}$-dependent manner, but the sperm motility declined rapidly.

Treatment of spermatozoa suspended in Medium MCM-PL with ouabain ( $0.1 \mathrm{mM})$ did not induce a shorter capacitation time compared with control spermatozoa suspended in Medium MCM-PL with a similar concentration of sodium chloride. Spermatozoa in both treatments were incubated for $0 \cdot 5,1 \cdot 0,1 \cdot 5$ and $2 \cdot 0 \mathrm{~h}$, with $\mathrm{Ca}^{2+}(5 \mathrm{mM}$, final concentration) being added for the final $10 \mathrm{~min}$. The percentages of sperm acrosome reactions were similar for both treatments at all incubation times.

Spermatozoa incubated for $3 \mathrm{~h}$ in a sucrose-based $\mathrm{Na}^{+}$-deficient Medium MCM-PL ( $\sim 45 \mathrm{mM}-$ $\mathrm{Na}^{+}$) with no added $\mathrm{K}^{+}$did not undergo acrosome reactions in response to the addition of $\mathrm{Ca}^{2+}$. If the spermatozoa were centrifuged and transferred to complete Medium MCM-PL before the addition of $\mathrm{Ca}^{2+}$, the motile spermatozoa still gave no acrosome reactions (data not shown). Similarly, if spermatozoa were incubated for $3 \mathrm{~h}$ in Medium MCM-PL containing an extra 10 $\mathrm{mM}-\mathrm{K}^{+}$, the percentage of motile spermatozoa that underwent acrosome reactions in response to the addition of $\mathrm{Ca}^{2+}$ was significantly reduced (Table 2$)$. However, the addition of ouabain $(0 \cdot 1 \mathrm{~mm})$

Table 2. The effect of $\mathrm{K}^{+}$and ouabain on the guineapig sperm acrosome reaction

\begin{tabular}{lc}
\hline \multicolumn{1}{c}{ Medium } & $\%$ Acrosome reactions \\
\hline Control & $56 \cdot 7 \pm 5 \cdot 8$ \\
$10 \mathrm{mM}-\mathrm{KCl}$ & $11 \cdot 0 \pm 2 \cdot 7$ \\
$10 \mathrm{mM}-\mathrm{KCl}+0 \cdot 1 \mathrm{mM}$-ouabain & $55 \cdot 3 \pm 2 \cdot 7$ \\
$0.1 \mathrm{mM}-$-oubain & $68 \cdot 3 \pm 8 \cdot 8$ \\
\hline
\end{tabular}

Spermatozoa were incubated for $3 \mathrm{~h}$ in Medium MCMPL with or without $\mathrm{K}^{+}$and/or ouabain as indicated. $\mathrm{Ca}^{2+}$ (final concentration $5 \mathrm{mM}$ ) was added for the last $10 \mathrm{~min}$ of the incubation and the percentage acrosome reaction was then assessed. The percentage of motile spermatozoa was not significantly different for any of the treatments and varied between 50 and $70 \%$, although the medium containing 10 mM-KCl supported better sperm motility in comparison with the other treatments. Values shown are the mean \pm s.e.m. of 3 animals. 
and $\mathrm{K}^{+}(10 \mathrm{mM})$ to the spermatozoa suspended in Medium MCM-PL overcame the $\mathrm{K}^{+}$inhibition of the sperm acrosome reaction after incubation for $3 \mathrm{~h}$ (Table 2).

\section{Ultrastructural observations}

Guinea-pig spermatozoa isolated from the epididymis agglutinate spontaneously to form well ordered stacks by head-to-head association (Green, 1978; Bearer \& Friend, 1982). After capacitation of the spermatozoa by incubation in Medium MCM-PL for $>2 \mathrm{~h}$, spermatozoa lying in mid- or para-sagittal section were scored for evidence of the acrosome reaction. Sections were initially examined under the light microscope $(\times 1250)$ and were classified as (a) acrosome intact, (b) swelling of the acrosome or (c) acrosome reaction complete and acrosomal matrix no longer apparent. Spermatozoa capacitated in Medium MCM-PL showed 65-80\% cells with acrosome intact, $15-25 \%$ cells with acrosomal swelling and $<10 \%$ spermatozoa had reacted acrosomes. Within $30 \mathrm{sec}$ of addition of $\mathrm{Ca}^{2+}$ to spermatozoa capacitated in Medium MCM-PL, 40-45\% had intact acrosomes, $50-55 \%$ showed acrosomal swelling and $<10 \%$ had reacted acrosomes. By 5 min after the addition of $\mathrm{Ca}^{2+},<10 \%$ of spermatozoa had intact acrosomes, $30-35 \%$ showed acrosomal swelling and $50-60 \%$ had reacted acrosomes.

Upon the addition of $\mathrm{Ca}^{2+}$ to spermatozoa capacitated in medium MCM-PL, the initial changes in the morphology of spermatozoa undergoing acrosome reactions were characterized by the formation of membrane-bound vesicles in the acrosomal cap region as well as swelling (i.e. cavitation) of the acrosome matrix (Pl. 1, Fig. 1). As the acrosome reaction proceeded, the contents of the acrosomal matrix became less electron dense as the acrosomal material dispersed and numerous vesicles were formed, particularly posterior to the acrosomal cap where the acrosome overlies the sperm nucleus. The vesicles appeared to form by multiple fusion of the plasma membrane and outer acrosomal membrane and proceeded posteriorly to the equatorial segment and eventually detached from the sperm head (Pl. 1, Fig. 2). Thus, when the acrosome reaction was completed, all the acrosomal components were absent from the sperm head except for the inner acrosomal membrane and the equatorial segment of the acrosome.

When capacitated spermatozoa were washed and resuspended in media containing no added $\mathrm{Na}^{+}$and then incubated in the presence of $\mathrm{Ca}^{2+}$ for 5-10 min before fixation, many spermatozoa showed swelling of the acrosomal matrix (Pl. 2, Fig. 3). When sections were examined under the light microscope, these spermatozoa showed 15-25\% acrosomal swelling before the addition of $\mathrm{Ca}^{2+}, 30-40 \%$ acrosomal swelling $5 \mathrm{~min}$ after, and $45-65 \%$ acrosomal swelling $10 \mathrm{~min}$ after the addition of $\mathrm{Ca}^{2+}$. However, little membrane vesiculation had occurred except for a series of vesicles which formed adjacent to the inner acrosomal membrane overlying the nucleus and within the acrosomal matrix (Pl. 2, Fig. 4). These vesicles were membrane-bound and were possibly formed by vesiculation of the outer acrosomal membrane as the swollen acrosomal matrix collapsed to lie adjacent to the sperm nucleus.

There was no observation of vesicles formed by fusion of the outer acrosomal membrane with the plasma membrane, indicating that $\mathrm{Na}^{+}$is required for this process. If the spermatozoa were fixed 5 min after the addition of $\mathrm{Ca}^{2+}$, the spermatozoa showing swelling of the acrosomal matrix appeared to have an intact plasma membrane overlying the acrosome (P1. 2, Fig. 3); however, 10 min after the addition of $\mathrm{Ca}^{2+}$ many of these spermatozoa had lost the plasma membrane overlying the acrosome and the swollen acrosomal matrix was bound by the outer acrosomal membrane (Pl. 2, Figs 4, 5 \& 6).

Spermatozoa capacitated in Medium-PL before being twice washed and re-suspended in a saline-based medium buffered at pH 6.6 and subsequently incubated for an additional $10 \mathrm{~min}$ in the presence of $\mathrm{Ca}^{2+}$ showed 35-40\% spermatozoa with intact acrosomes, 50-60\% spermatozoa with acrosomal swelling, and $<10 \%$ of spermatozoa that had reacted acrosomes, when sections were examined by light microscopy. In contrast, sections of spermatozoa that were incubated for $3 \mathrm{~h}$ in $\mathrm{Na}^{+}$-deficient Medium MCM-PL $\left(\sim 45 \mathrm{mM}-\mathrm{Na}^{+}\right)$showed $65-80 \%$ cells with intact acrosomes, 15 

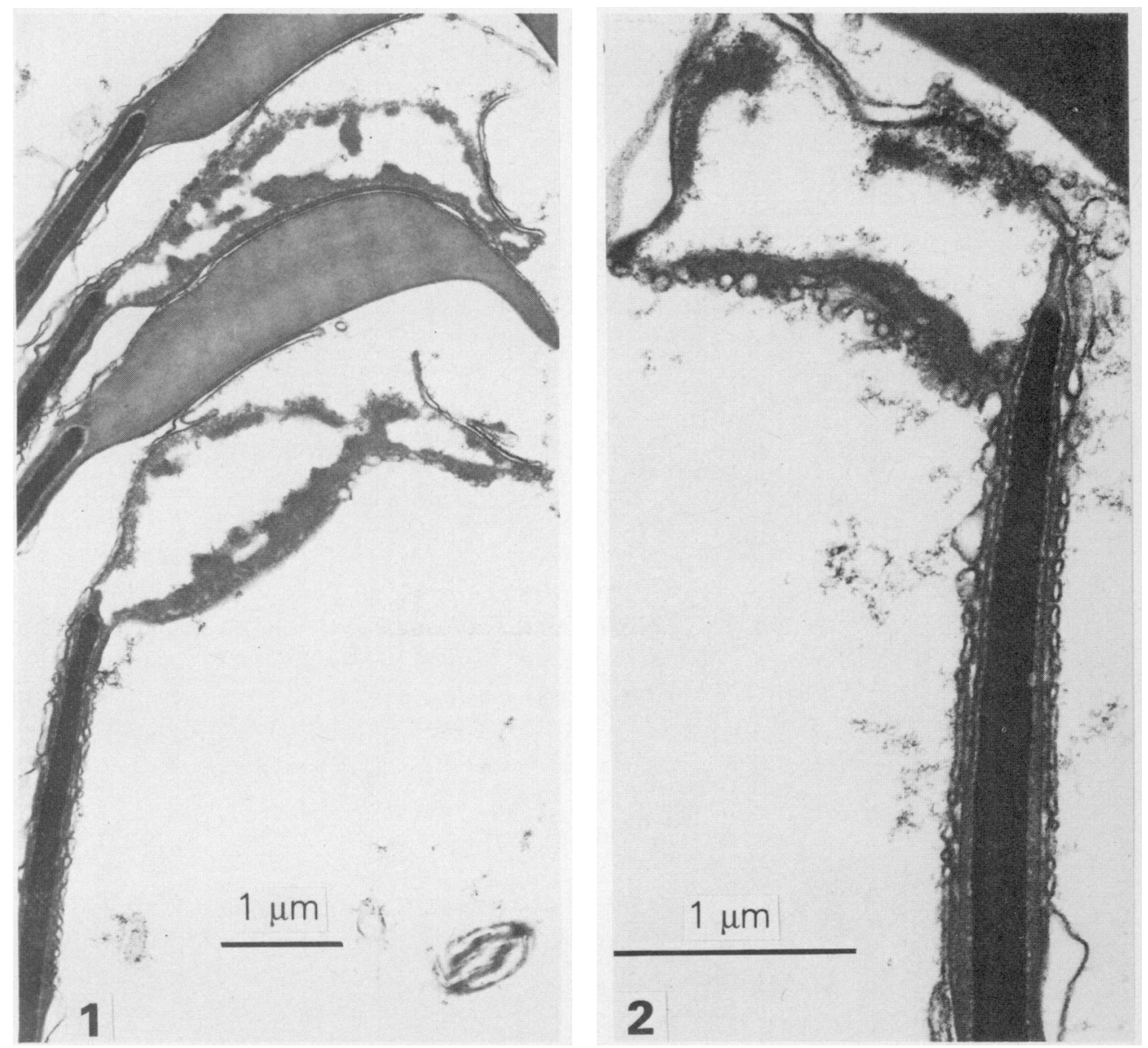

Response of a stack of guinea-pig spermatozoa to $\mathrm{Ca}^{2+}$ after incubation in Medium MCM-PL. Spermatozoa were incubated in Medium MCM-PL for $135 \mathrm{~min}$, then $5 \mathrm{mM}^{-\mathrm{Ca}^{2+}}$ (final conc.) was added and the incubation continued for an additional $10 \mathrm{~min}$ before fixation.

Fig. 1. In the centre is a sperm head which has not yet undergone an acrosome reaction. Immediately above and below the intact spermatozoon are two spermatozoa which are in an early stage of the acrosome reaction. The acrosomal matrix of these spermatozoa has expanded to form a large cavity, and vesiculation of the plasma membrane and outer acrosomal membrane is evident.

Fig. 2. Membrane fusion of another spermatozoon that is in the terminal stage of an acrosome reaction, showing a series of membrane-bound vesicles apparently formed by fusion of the plasma membrane overlying the outer acrosomal membrane. 
PLATE 2
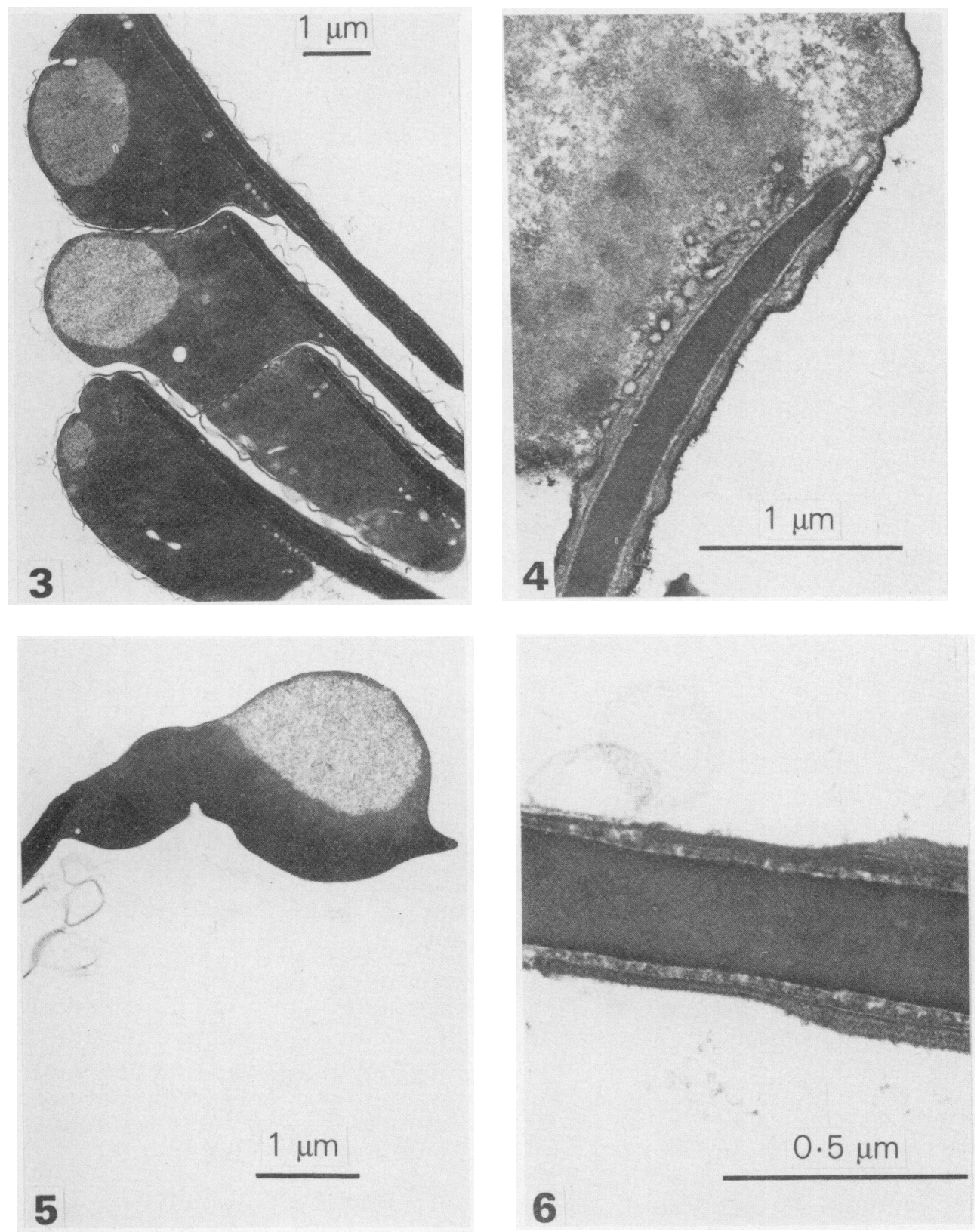
$25 \%$ cells with acrosomal swelling and $<10 \%$ spermatozoa with reacted acrosomes. Similar results were obtained in the presence or absence of added $\mathrm{Ca}^{2+}$.

\section{Discussion}

This report presents evidence suggesting that one component of the capacitation process in guinea-pig spermatozoa in vitro requires an increase in intracellular $\mathrm{Na}^{+}$. This is indicated by experiments in which freshly collected spermatozoa treated with the monovalent ionophore monensin showed rapid acrosome reactions in the presence of both extracellular $\mathrm{Ca}^{2+}$ and extracellular $\mathrm{Na}^{+}$. In addition, spermatozoa incubated in an isotonic sucrose-based $\mathrm{Na}^{+}$-deficient medium ( $\left.\sim 45 \mathrm{~mm}-\mathrm{Na}^{+}\right)$for $3 \mathrm{~h}$ did not undergo acrosome reactions in response to the addition of $\mathrm{Ca}^{2+}$, compared with spermatozoa incubated in capacitating medium containing $\mathrm{Na}^{+}(\sim 150 \mathrm{mM}-$ $\mathrm{Na}^{+}$). It has been demonstrated previously that sucrose does not inhibit the development of the guinea-pig acrosome reaction (Rogers \& Yanagimachi, 1975).

The intracellular $\mathrm{Na}^{+}$concentration of freshly collected guinea-pig epididymal spermatozoa is very low (2-3 mM-Na ${ }^{+}$), but increases approximately 4-fold $\left(12 \mathrm{~mm}-\mathrm{Na}^{+}\right)$after incubation for $2 \mathrm{~h}$ in physiological medium containing $\mathrm{Na}^{+}$and $\mathrm{K}^{+}(\mathrm{Rink}, 1977)$. This increase in intracellular $\mathrm{Na}^{+}$is even more substantial after incubation in $\mathrm{K}^{+}$-free medium containing ouabain, an inhibitor of $\left(\mathrm{Na}^{+}, \mathrm{K}^{+}\right)$-ATPase (Rink, 1977). At $\mathrm{pH} \mathrm{7 \cdot 0,} \mathrm{a}\left(\mathrm{Na}^{+}, \mathrm{K}^{+}\right)$-ATPase, without divalent ion requirement, has been demonstrated cytochemically to be present on the plasmalemma that overlies the guinea-pig sperm acrosome (Gordon, Dandekar \& Eager, 1978). However, treatment of the spermatozoa with ouabain when suspended in $\mathrm{K}^{+}$-free medium did not induce a more rapid onset of the acrosome reaction rate, possibly because the efflux of $\mathrm{Na}^{+}$is inhibited to about the same extent, either by the removal of $\mathrm{K}^{+}$or the addition of ouabain (Robinson \& Flashner, 1979). Such a result is consistent with the proposal that the $\mathrm{Na}^{+}, \mathrm{K}^{+}$pump participates in the sperm capacitation process (Mrsny \& Meizel, 1981). In contrast, the addition of $\mathrm{K}^{+}$to capacitating medium inhibits the development of a high percentage of acrosome reactions (Rogers et al., 1981) possibly because the sperm $\left(\mathrm{Na}^{+}, \mathrm{K}^{+}\right)$-ATPase can now effect $\mathrm{Na}^{+} / \mathrm{K}^{+}$exchange and thus maintain low intracellular $\mathrm{Na}^{+}$concentrations. The ability of ouabain to prevent the $\mathrm{K}^{+}$inhibition is consistent with this proposal.

Monensin is known to catalyse an initial electrical neutral $\mathrm{Na}^{+}$in $/ \mathrm{H}^{+}$out exchange across cell membranes (Henderson, McGivan \& Chappell, 1969; Reed, 1982) so it is possible that the requirement of guinea-pig spermatozoa for extracellular $\mathrm{Na}^{+}$during capacitation is primarily linked to an increase in intracellular $\mathrm{pH}$ resulting from the $\mathrm{Na}^{+} / \mathrm{H}^{+}$exchange. However, treatment of capacitated spermatozoa suspended in $\mathrm{Na}^{+}$-free medium with $\mathrm{Ca}^{2+}$ in the presence of $\mathrm{NH}_{4} \mathrm{Cl}$,

\section{PLATE 2}

Response of capacitated spermatozoa, suspended in $\mathrm{Na}^{+}$-free media, to $\mathrm{Ca}^{2+}$ after preincubation for $135 \mathrm{~min}$ in Medium MCM-PL.

Fig. 3. A stack of spermatozoa suspended in medium composed of $300 \mathrm{~mm}$-sucrose, $1 \mathrm{mM}$ $\mathrm{MgCl}_{2}, 10 \mathrm{mM}$-Tris (pH 7.8) and $5 \mathrm{mM}-\mathrm{CaCl}_{2}$ for $5 \mathrm{~min}$ after preincubation in Medium MCMPL. The acrosomal matrices of these spermatozoa have expanded, but the plasma membranes appear intact.

Fig. 4. A spermatozoon suspended in medium composed of $178 \mathrm{~mm}$-choline chloride, $1 \mathrm{mM}$ $\mathrm{MgCl}_{2}, 10 \mathrm{mM}$-Tris (pH 7.8) and $5 \mathrm{mM}-\mathrm{CaCl}_{2}$, for $10 \mathrm{~min}$ after preincubation in Medium MCM-PL. The acrosomal matrix has expanded and is bound by the outer acrosomal membrane.

Fig. 5. A spermatozoon incubated in the sucrose-based medium for $10 \mathrm{~min}$. The acrosomal matrix has expanded.

Fig. 6. The equatorial segment of the same spermatozoon as in Fig. 5 at higher magnification showing the loss of the plasma membrane overlying the acrosome. 
which has been used to increase intracellular $\mathrm{pH}$ in various cell types (Winkler \& Grainger, 1978), did not allow induction of the acrosome reaction. Therefore, an increase in intracellular $\mathrm{pH}$ is not likely to be the prime stimulator of the acrosome reaction. In addition, measurements of acid efflux from capacitated spermatozoa, suspended in saline-based medium or $\mathrm{Na}^{+}$-free medium, were similar in both treatments in response to the addition of $\mathrm{Ca}^{2+}$.

Changes in $\mathrm{Na}^{+}$permeability produced by monensin could activate the sperm acrosome reaction because of an elevation of intracellular $\mathrm{Na}^{+}$concentrations. Moreover, amiloride, a compound that inhibits passive $\mathrm{Na}^{+}$transport in a number of mammalian cell types (Salako \& Smith, 1970; Smith et al., 1982), retarded the onset of acrosome reactions of spermatozoa incubated in capacitating medium. A reversible $\mathrm{Na}^{+} / \mathrm{Ca}^{2+}$ carrier or antiporter has been demonstrated on plasma membrane vesicles isolated from ram spermatozoa (Bradley \& Forrester, 1980) and boar spermatozoa (Ashraf, Peterson \& Russell, 1982), and is similar to the $\mathrm{Na}^{+} / \mathrm{Ca}^{2+}$ exchange system operating across the plasma membrane of cells from a variety of excitable tissues and erythrocytes (Reeves \& Sutko, 1979; Smith et al., 1982; Philipson \& Nishimoto, 1982). Studies on the $\mathrm{Na}^{+} / \mathrm{Ca}^{2+}$ antiporter of cardiac sarcolemmal vesicles indicate that the intracellular $\mathrm{Na}^{+}$-dependent $\mathrm{Ca}^{2+}$ influx in an intact myocardial cell has an especially steep dependence on a $\mathrm{Na}^{+}$concentration between 8 and $12 \mathrm{mM}$ (Philipson \& Nishimoto, 1982). This is close to in-vivo intracellular $\mathrm{Na}^{+}$ activity and indicates that small changes in intracellular $\mathrm{Na}^{+}$levels can have a substantial effect on $\mathrm{Ca}^{2+}$ influx (Smith et al., 1982) and hence cell response.

Spermatozoa capacitated in Medium MCM-PL before being washed twice and resuspended in $\mathrm{Na}^{+}$-deficient media do not give acrosome reactions in response to addition of $\mathrm{Ca}^{2+}$, as seen by phase-contrast microscopy. Examination under the electron microscope shows that some of the spermatozoa respond to the addition of $\mathrm{Ca}^{2+}$ and undergo swelling or cavitation of the acrosomal matrix, but no membrane fusion occurs between the plasma membrane and the outer acrosomal membrane. Cavitation of the acrosome of spermatozoa suspended in these $\mathrm{Na}^{+}$-deficient media appeared to occur before disruption of the plasma membrane overlying the acrosome. The results suggest that cavitation of the acrosome is $\mathrm{a} \mathrm{Ca}^{2+}$-dependent event that precedes membrane fusion during the acrosome reaction of guinea-pig spermatozoa, as suggested previously (Yanagimachi $\&$ Usui, 1974). $\mathrm{Ca}^{2+}$ entry possibly occurs in these capacitated spermatozoa suspended in $\mathrm{Na}^{+}$deficient media as evidenced by disruption of the plasma membrane overlying the acrosome. However, extracellular $\mathrm{Na}^{+}$ions are required at relatively high concentration $(>125 \mathrm{~mm})$ for fusion of the plasma membrane with the outer acrosomal membrane.

A working model to explain the effects of inducers such as monensin or serum (Hyne \& Garbers, 1981) on the guinea-pig acrosome reaction can be postulated, based on the mechanisms discussed above. In the absence of inducer, the $\left(\mathrm{Na}^{+}, \mathrm{K}^{+}\right)$-ATPase maintains a low intracellular $\mathrm{Na}^{+}$and high intracellular $\mathrm{K}^{+}$concentration by pumping $\mathrm{Na}^{+}$out of the cell and $\mathrm{K}^{+}$into the cell. The consequent $\mathrm{Na}^{+}$gradient can then be used to pump $\mathrm{Ca}^{2+}$ out of the spermatozoon by coupling the two ion movements via a $\mathrm{Na}^{+} / \mathrm{Ca}^{2+}$ antiporter. During sperm capacitation in medium containing no added $\mathrm{K}^{+}$or in medium supplemented with serum, reduced $\left(\mathrm{Na}^{+}, \mathrm{K}^{+}\right)$pump activity causes a sufficient increase in cytoplasmic $\mathrm{Na}^{+}$to reverse the direction of the $\mathrm{Na}^{+} / \mathrm{Ca}^{2+}$ antiporter. This allows $\mathrm{Ca}^{2+}$ to enter the spermatozoon and the increased cellular $\mathrm{Ca}^{2+}$ concentration activates a series of events which lead to the acrosome reaction. The demonstration of a $\mathrm{Na}^{+} / \mathrm{Ca}^{2+}$ antiporter in the guinea-pig sperm plasma membrane overlying the acrosome and a description of a functional role in the acrosome reaction would support this model.

A characteristic feature of the fluid from the cauda epididymidis of mammals, including the guinea-pig, is a low $\mathrm{Na}^{+}$concentration $(\sim 20 \mathrm{mM})$ and an acidic $\mathrm{pH}$, in contrast to the composition of blood or other reproductive tract fluids (Jones, 1978). The results from these studies indicate that the low concentration of $\mathrm{Na}^{+}$and acidic $\mathrm{pH}$ of the luminal fluid would prevent the premature acquisition of fertilizing ability by spermatozoa stored in the cauda epididymidis.

This study was supported, in part, by N.H. \& M.R.C. (Australia) grants to R.V.H. and A.L. 


\section{References}

Ashraf, M., Peterson, R.N. \& Russell, L.D. (1982) Evidence for $\mathrm{Ca}^{2+} / \mathrm{Na}^{+}$antiport in boar sperm plasma membrane vesicles. Biol. Reprod. 26, Suppl. 1, 37A, abstr.

Barros, C. (1974) Capacitation of mammalian spermatozoa. In Physiology and Genetics of Reproduction, Part B, pp. 3-24. Eds E. M. Coutinho \& F. Fuchs. Plenum Press, New York.

Barros, C., Bedford, J.M., Franklin, L.E. \& Austin, C.R. (1967) Membrane vesiculation as a feature of the mammalian acrosome reaction. J. Cell Biol. 34, $\mathrm{Cl}$ C5.

Bearer, E.L. \& Friend, D.S. (1982) Modifications of anionic-lipid domains preceding membrane fusion in guinea pig sperm. J. Cell Biol. 92, 604-615.

Bradley, M.P. \& Forrester, I.T. (1980) A sodium-calcium exchange mechanism in plasma membrane vesicles isolated from rat sperm flagella. FEBS Letters 121, 15-18.

Collins, F. \& Epel, D. (1977) The role of calcium ions in the acrosome reaction of sea urchin sperm. Regulation of exocytosis. Expl Cell Res. 106, 211-222.

Dan, J.C. (1954) Studies on the acrosome. III. Effect of calcium deficiency. Biol. Bull. mar. Biol. Lab. Woods Hole 107, 335-349.

Dan, J.C. (1967) Acrosome reaction and lysins. In Fertilization. Comparative Morphology, Biochemistry, and Immunology, Vol. 1, pp. 237-293. Eds C. B. Metz \& A. Monroy. Academic Press, New York.

Goodall, M.C. (1970) Structural effects in the action of antibiotics on the ion permeability of lipid bilayers. III. Gramicidins " $A$ " and "S" and lipid specificity. Biochim. biophys. Acta 219, 471-478.

Gordon, M., Dandekar, P.V. \& Eager, P.R. (1978) Identification of phosphatases on the membranes of guinea pig sperm. Anat. Rec. 191, 123-134.

Green, D.P.L. (1978) The induction of the acrosome reaction in guinea-pig sperm by the divalent metal cation ionophore A23187. J. Cell Sci. 32, 137-151.

Henderson, P.J.F., McGivan, J.D. \& Chappell, J.B. (1969) The action of certain antibiotics on mitochondrial, erythrocyte and artificial phospholipid membranes. The role of induced proton permeability. Biochem. J. 111, 521-535.

Hyne, R.V. \& Garbers, D.L. (1979) Calcium-dependent increase in adenosine $3^{\prime}, 5^{\prime}$-monophosphate and induction of the acrosome reaction in guinea pig spermatozoa. Proc. natn. Acad. Sci. U.S.A. 76, 56995703.

Hyne, R.V. \& Garbers, D.L. (1981) Requirement of serum factors for capacitation and the acrosome reaction of guinea pig spermatozoa in buffered medium below pH 7.8. Biol. Reprod. 24, 257-266.

Hyne, R.V. \& Garbers, D.L. (1982) Effects of putative protease inhibitors on the acrosome reaction of sea urchin spermatozoa. J. Reprod. Fert. 66, 51-55.

Johnson, J.D., Epel, D. \& Paul, M. (1976) Intracellular $\mathrm{pH}$ and activation of sea urchin eggs after fertilization. Nature, Lond. 262, 661-664.

Jones, R. (1978) Comparative biochemistry of mammalian epididymal plasma. Comp. Biochem. Physiol. B 61, 365-370.

Miyamoto, H. \& Ishibashi, T. (1975) The role of calcium ions in fertilization of mouse and rat eggs in vitro. $J$. Reprod. Fert. 45, 523-526.

Mrsny, R.J. \& Meizel, S. (1981) Potassium ion influx and $\mathrm{Na}^{+}, \mathrm{K}^{+}$-ATPase activity are required for the hamster sperm acrosome reaction. J. Cell Biol. 91, 77-82.

Philipson, K.D. \& Nishimoto, A.Y. (1982) $\mathrm{Na}^{+}-\mathrm{Ca}^{2+}$ exchange in inside-out cardiac sarcolemnal vesicles. J. biol. Chem. 257, 5111-5117.

Poste, G. \& Allison, A.C. (1973) Membrane fusion. Biochim. biophys. Acta 300, 421-465.

Reed, P.W. (1982) Biochemical and biological effects of carboxylic acid ionophores. In Polyether Antibiotics. Naturally Occurring Acid Ionophores, Vol. 1, pp. 185302. Ed. J. W. Westley. Marcel Dekker, New York.

Reeves, J.P. \& Sutko, J.L. (1979) Sodium-calcium ion exchange in cardiac membrane vesicles. Proc. natn. Acad. Sci. U.S.A. 76, 590-594.

Rink, T.J. (1977) Membrane potential of guinea-pig spermatozoa. J. Reprod. Fert. 51, 155-157.

Robinson, J.D. \& Flashner, M.S. (1979) The $\left(\mathrm{Na}^{+}+\right.$ $\mathrm{K}^{+}$)-activated ATPase. Enzymatic and transport properties. Biochim. Biophys. Acta 549, 145-176.

Rogers, B.J. \& Yanagimachi, R. (1975) Retardation of guinea pig sperm acrosome reaction by glucose. The possible importance of pyruvate and lactate metabolism in capacitation and the acrosome reaction. Biol. Reprod. 13, 568-575.

Rogers, B.J., Ueno, M. \& Yanagimachi, R. (1981) Fertilization by guinea pig spermatozoa requires potassium ions. Biol. Reprod. 25, 639-648.

Salako, L.A. \& Smith, A.J. (1970) Changes in sodium pool and kinetics of sodium transport in frog skin produced by amiloride. Br. J. Pharmac. 39, 99-109.

Schackmann, R.W. \& Shapiro, B.M. (1981) A partial sequence of ionic changes associated with the acrosome reaction of Strongylocentrotus purpuratus. Devl Biol. 81, 145-154.

Schackmann, R.W., Eddy, E.M. \& Shapiro, B.M. (1978) The acrosome reaction of Strongylocentrotus purpuratus sperm. Ion requirements and movements. Devl Biol. 65, 483-495.

Schackmann, R.W., Christen, R. \& Shapiro, B.M. (1981) Membrane potential depolarization and increased intracellular $\mathrm{pH}$ accompany the acrosome reaction of sea urchin sperm. Proc. natn. Acad. Sci. U.S.A. 78, 6066-6070.

Singh, J.P., Babcock, D.F. \& Lardy, H.A. (1978) Increased calcium-ion influx is a component of capacitation of spermatozoa. Biochem. J. 172, 549556.

Smith, R.L., Macara, I.G., Levenson, R., Housman, D. \& Cantley, L. (1982) Evidence that a $\mathrm{Na}^{+} / \mathrm{Ca}^{2+}$ antiporter system regulates murine erythroleukemia cell differentiation. J. biol. Chem. 257, 773-780.

Suchard, S.J., Lattanzio, F.A., Jr, Rubin, R.W. \& Pressman, B.C. (1982) Stimulation of catecholamine secretion from cultured chromaffin cells by an ionophore-mediated rise in intracellular sodium. $J$. Cell Biol. 94, 531-539.

Toyoda, Y. \& Chang, M.C. (1974) Capacitation of epididymal spermatozoa in medium with high $\mathrm{K}^{+} / \mathrm{Na}$ ratio and cyclic AMP for the fertilization of rat eggs in vitro. J. Reprod. Fert. 36, 125-134. 
Winkler, M.M. \& Grainger, J.L. (1978) Mechanism of action of $\mathrm{NH}_{4} \mathrm{Cl}$ and other weak bases in the activation of sea urchin eggs. Nature, Lond. 273, 536-538.

Wong, P.Y.D., Lee, W.M. \& Tsang, A.Y.F. (1981) The effects of extracellular sodium on acid release and motility initiation in rat caudal epididymal spermatozoa in vitro. Expl Cell Res. 131, 97-104.
Yanagimachi, R. (1975) Acceleration of the acrosome reaction and activation of guinea pig spermatozoa by detergents and other reagents. Biol. Reprod. 13, 519 526.

Yanagimachi, R. \& Usui, N. (1974) Calcium dependence of the acrosome reaction and activation of guinea pig spermatozoa. Expl Cell Res. 89, 161-174.

Received 14 April 1983 